\title{
Context-specific roles for paracrine IL-6 in lymphomagenesis
}

\author{
Luke A. Gilbert and Michael T. Hemann ${ }^{1}$ \\ The Koch Institute for Integrative Cancer Research at Massachusetts Institute of Technology, Massachusetts Institute \\ of Technology, Cambridge, Massachusetts 02139, USA
}

\begin{abstract}
A basic requirement for the development of complex organ systems is that the cellular response to identical environmental cues can vary significantly between distinct cell types and developmental stages. While it is well established that paracrine signaling can similarly elicit diverse responses in distinct tumor types, the relevance of developmental stage-specific signaling responses to tumor development remains unclear. Here, we show that the same microenvironmental factor, IL-6, can both promote and prevent lymphoma development by acting on cells at distinct stages of hematopoietic development. Specifically, paracrine IL-6 signaling promotes the survival of transplanted hematopoietic stem cells following lethal irradiation, allowing for the persistence and expansion of progenitor cells bearing a cancer-promoting alteration. Conversely, IL-6 signaling also initiates a paracrine secretory program in the bone marrow that promotes B-cell differentiation and inhibits the development of B-cell malignancies. Thus, stage-specific responses to cytokines may promote progenitor cell expansion while also inhibiting neoplastic development within a single developmental lineage. Once transformed, the resulting B-cell lymphomas again use paracrine IL-6 signaling as a survival signal, highlighting the ability of tumor cells to co-opt pathways used for stem cell protection. These data not only suggest a complex regulation of tumor development by the preneoplastic microenvironment, but also that this regulation can decisively impact the outcome of wellestablished tumor modeling approaches.
\end{abstract}

[Keywords: IL-6; IL-10; B cell; E $\mu$-myc; tumor microenvironment; stem cell]

Supplemental material is available for this article.

Received January 24, 2012; revised version accepted June 21, 2012.

Maintaining tissue homeostasis requires the ability to replace damaged cells. In many organs, this regenerative potential is maintained by long-lived tissue-specific adult stem cells. These cells are largely quiescent, enabling more efficient DNA repair and suppression of apoptosis (Mohrin et al. 2010; Mandal et al. 2011). In response to cellular stress, adult stem cells are induced to both proliferate and differentiate to reconstitute organ systems (Beltrami et al. 2003). However, the mechanisms promoting stem cell reentry into the cell cycle following tissue injury are less understood. Recent evidence suggests that in some tissues, paracrine survival factors promote normal stem cell homeostasis and also modulate stem cell survival and tissue repair in response to DNA damage (Ashton et al. 2010; Butler et al. 2010; Blanpain et al. 2011).

The activation of adult stem cells to promote tissue homeostasis is particularly important in the hematopoietic system. All differentiated hematopoietic cells have a transient life span; thus, each of these cell types needs to be regenerated on an ongoing basis. Additionally, exogenous

${ }^{1}$ Corresponding author

E-mail hemann@mit.edu

Article is online at http://www.genesdev.org/cgi/doi/10.1101/gad.197590.112. stresses from insults like hemorrhage and chemotherapy require the stimulation of progenitor cells to reconstitute the hematopoietic compartment. This requirement for paracrine signaling is not specific to bona fide hematopoietic stem cells (HSCs), as differentiated hematopoietic cell types also require ongoing paracrine signaling to complete terminal steps of differentiation (Rothenberg et al. 2008). For example, in the B-cell lineage, BAFF and IL-21 synergize to activate and differentiate memory B cells into plasma cells (Ettinger et al. 2005, 2007; Kuchen et al. 2007). Additionally, emerging evidence suggests that the requirement for specific paracrine growth factor signaling is highly context-specific during development. For example, mice that express constitutively active Stat $5 b$, a central mediator of IL-7 receptor signaling, show a dramatic expansion of pro/pre-B cells and mature T cells but not mature B cells or pro-T cells (Burchill et al. 2003). This suggests that during hematopoiesis, the activation of a given receptor may exert dramatically distinct effects, depending on cell type or stage of differentiation.

Paracrine survival factors are also important in the growth and survival of transformed cells. For example, in multiple myeloma, multiple factors emanating from the bone marrow microenvironment are essential for tumor 
progression (Hideshima et al. 2007). Additionally, we showed recently that survival signals important for T-cell survival and thymic regeneration can be co-opted by hematopoietic malignancies to promote tumor cell survival and fuel tumor progression /Gilbert and Hemann 2010). Specifically, DNA damage induces the acute release of prosurvival cytokines, including IL-6, from tumorassociated endothelial cells, and these paracrine factors act to prevent lymphoma cell apoptosis and promote tumor relapse. Thus, survival signaling promotes normal tissue repair but can also promote tumor persistence in select microenvironments.

While stem and tumor cells are receptive to stressinduced paracrine signaling, it remains unclear whether preneoplastic cells can use these same survival signals to bypass apoptotic barriers early in tumor development (Hanahan and Weinberg 2011). Tumor development is a multistep process in which normal growth and differentiation control is lost (Hanahan and Weinberg 2000). This process, at its most basic level, requires the activation of a proto-oncogene to drive proliferation. For example, deregulated expression of c-Myc as a result of aberrant VDJ recombination, resulting in the $t(8 ; 14)$ translocation, provides the initiating lesion in Burkitt's lymphoma (Haluska et al. 1986; Harris et al. 1988). Paradoxically, however, this initiating lesion also engages a crucial barrier to tumor development, as oncogenic signaling in preneoplastic cells can promote apoptosis or senescence (Serrano et al. 1997; Zindy et al. 1998; Hemann et al. 2005; Michaloglou et al. 2005). Thus, it remains unclear how rare preneoplastic cells survive during the period after oncogene activation but prior to the loss of a tumor suppressor.

Given the role of IL-6 in promoting lymphoma cell survival in a therapeutic context, we wondered whether this cytokine can also potentiate early lymphoma development by promoting cellular survival following oncogene activation. Surprisingly, we found that IL-6 could either promote or inhibit tumor development, depending on the experimental conditions and relevant preneoplastic cell type. While IL-6 facilitates the reconstitution of mice with HSCs bearing oncogenic alterations-a tumor-promoting activity-it also stimulates the maturation of pro/pre-B cells to more mature B cells. As pro/pre-B cells are more susceptible than mature B cells to oncogenic transformation, IL-6 supports a differentiation process that inhibits lymphoma development (Strasser et al. 1990; Lindeman et al. 1994; Kelly et al. 2007b, 2011). Thus, paracrine signaling can either support or inhibit tumor progression within a given lineage, a process that balances the beneficial effects of tissue regeneration with the detrimental effects of neoplastic development. Additionally, IL-6 promotes the survival of HSCs and maturing B-lymphoma cells, but not B-cell precursors, in response to cellular stress, suggesting that tumors cells reacquire the ability to respond to stem cell survival signals following transformation.

\section{Results}

Paradoxical roles for IL-6 in lymphoma development

To examine the role of paracrine IL-6 signaling in B-cell lymphomagenesis, we used an adoptive transfer approach in which $E \mu$-myc HSCs derived from fetal livers were transplanted into lethally irradiated wild-type or $I L-6^{-/-}$ recipient mice (Fig. 1A). This approach is frequently used to interrogate the role of defined alterations in normal or tumor development within the hematopoietic system. Following transplantation, all recipient mice developed B-cell lymphomas as assessed by tumor pathology and immunophenotype (Supplemental Fig. S1A,B). However, tumor latency varied considerably with recipient IL-6 status. Notably, $I L-6^{-/-}$recipient mice showed significantly delayed tumor onset when compared with control recipient mice $\left(I L-6^{-/-}\right.$mean survival of $415 \pm 49 \mathrm{~d}$ versus $I L-6^{+/+}$mean survival of $182 \pm 49 \mathrm{~d}, P=0.0093$ ) (Fig. 1A). Despite the differences in tumor latency, the resulting lymphomas in $I L-6^{+/+}$and $I L-6^{-/-}$mice showed a similar immunophenotype and histopathology (Supplemental Fig. S1A,B). To examine whether the difference in tumor onset could result from defective fetal liver HSC engraftment in the absence of IL-6, we measured the acute engraftment of fetal liver HSCs into $I L-6^{+/+}$and $I L-6^{-/-}$ mice. Here we observed no significant difference in fetal
A.
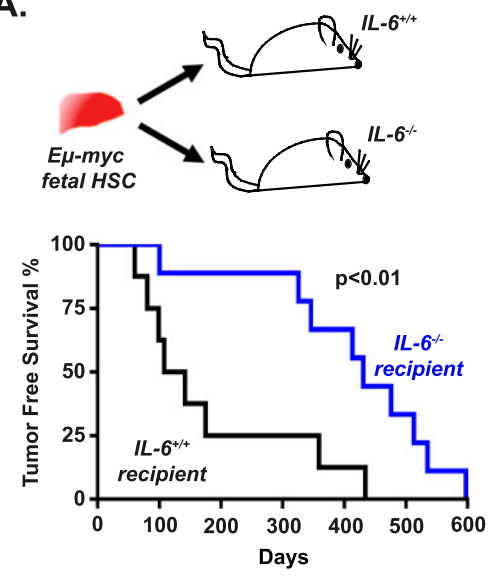

B.
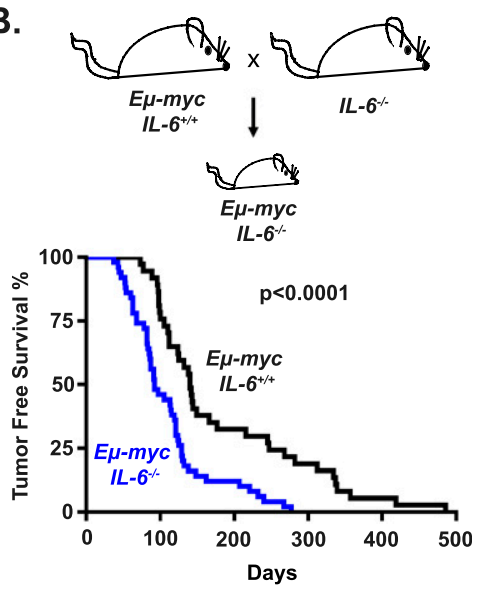

Figure 1. $I L-6$ status modulates $E \mu-M y c$ lymphomagenesis in a context-specific manner. $(A$, top) A schematic diagram depicting the adoptive transfer approach for transplantation of $E \mu-M y c$ fetal liver HSCs into $I L-6^{+/+}(n=8)$ or $I L-6^{-/-}(n=$ 9) mice. (Bottom) A Kaplan-Meier curve displaying tumor-free survival for both cohorts of mice. The $P$-value was calculated using a $\log$ rank test. $(B$, top $) \mathrm{A}$ schematic diagram depicting the generation of germline $E \mu-m y c ; I L-6^{-/-}$ and $E \mu-m y c ; I L-6^{+/+}$mice. (Bottom) A KaplanMeier curve displaying tumor-free survival for $E \mu-m y c ; I L-6^{-/-}(n=50)$ and $E \mu-m y c ; I L-6^{+/+}(n=$ 37) mice. The $P$-value was calculated using a logrank test. 
liver HSC engraftment $24 \mathrm{~h}$ following injection into lethally irradiated $I L-6^{+/+}$or $I L-6^{-/-}$mice (Supplemental Fig. S1C). As IL-6 has previously been shown not to play a role in mature lymphoma cell proliferation, these data suggest that paracrine IL-6 may support the survival of engrafted hematopoietic progenitors in vivo (Gilbert and Hemann 2010).

As a complementary strategy to examine the role of IL-6 in lymphoma development, $I L-6^{-/-}$mice were crossed with $E \mu-m y c$ mice to generate germline $E \mu-m y c ; I L-6^{-/-}$ mice (Fig. 1B). Again, all $E \mu-m y c$ mice developed B-cell lymphomas regardless of IL- 6 status. However, in this context, $E \mu-m y c ; I L-6^{-/-}$mice developed B-cell lymphomas more rapidly than control $E \mu-m y c$ mice $\left(I L-\sigma^{-l-}\right.$ mean survival of $110 \pm 8 \mathrm{~d}$ versus $I L-6^{+/+}$mean survival of $184.5 \pm 18 \mathrm{~d}, P=0.0001)$. Notably, the histopathology of lymphomas in $I L-6^{+/+}$and $I L-6^{-/-}$mice was similar in both the germline and transplant models, suggesting that IL-6 status affects tumor latency but not tumor phenotype in this model (Supplemental Fig. S1A). Thus, paradoxically, IL-6 loss can either accelerate or delay lymphomagenesis in $E \mu$-myc mice, depending on the specific construction of the mouse model.

\section{IL-6 promotes B-cell maturation}

To begin to reconcile these opposing roles for IL-6 in tumor development, we first examined lymphoma cell differentiation status in germline $E \mu$-myc mice in the presence and absence of IL- 6 . In the $E \mu$-myc model, premalignant oligoclonal B-cell expansion generally precedes monoclonal lymphomagenesis in which tumors are either surface immunoglobulin-positive or -negative but not mixed (Harris et al. 1988; Rempel et al. 2009). Notably, $E \mu-m y c ; I L-6^{-/-}$tumors were more immature and polyclonal, as assessed by surface IgM expression, than control $E \mu$-myc tumors (Fig. 2A; Supplemental Fig. S1D). This observation suggested that $I L-6$ deficiency might result in aberrant B-cell maturation. B-cell development is a complex process during which B cells pass through a series of developmental stages characterized by distinct patterns of surface markers. For B cells to develop, they require multiple survival signals from the bone marrow microenvironment, including IL-7, SCF, and adhesion-mediated survival signaling (Nagasawa 2006). As it is well established that IL- 6 is required for T-cell development and plasma cell maturation, we examined whether IL-6 is involved in early B-cell development or growth (Kopf et al. 1994; Hilbert et al. 1995). Here, we measured the percentage of pro/pre- and immature B cells (defined here as $\mathrm{CD} 19^{+} / \mathrm{IgM}^{-}$and $\mathrm{CD}_{1} 9^{+} / \mathrm{IgM}^{+}$, respectively) in the bone marrow of wild-type and $I L-6^{-/-}$mice. $I L-6^{-/-}$mice showed a similar overall B-cell number, but the ratio of pro/pre- to immature B cells was increased compared with wild-type bone marrow. Specifically, we observed decreased numbers of immature $\mathrm{B}$ cells and increased numbers of pro/pre-B cells in $I L-6^{-/-}$mice (Fig. 2B; Supplemental Fig. S2A). We also observed a decreased relative percentage of mature $\mathrm{B}$ cells (Hardy fraction $\mathrm{F}$ ) in $E \mu-m y c ; I L-6^{-/-}$compared with $E \mu-m y c ; I L-\sigma^{+/+}$mice (Supplemental Fig. S2B; Hardy et al. 2000). To further characterize this developmental defect, we measured the expression of CD24, CD43, and BP-1, three canonical cell surface markers associated with the pro/pre-B-cell transition, by flow cytometry in B cells from wild-type, $I L-6^{-/-}, E \mu-m y c ; I L-6^{+/+}$, and $E \mu-m y c ; I L-6^{-/-}$mice. Here
A.

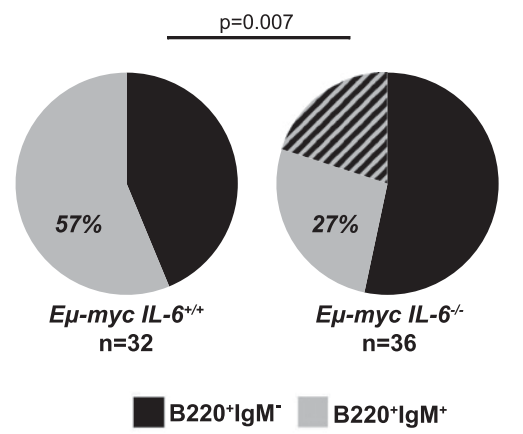

C.

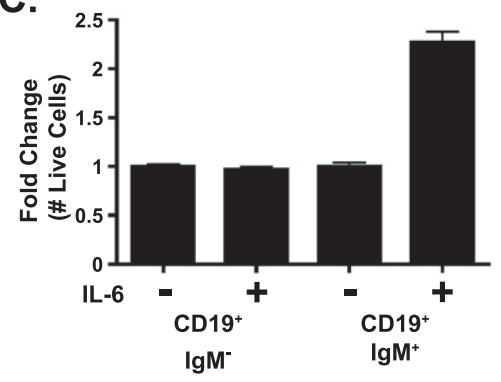

B.

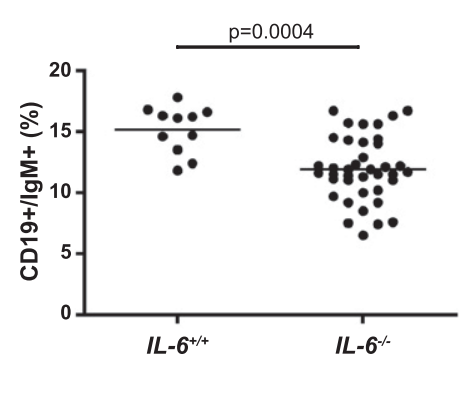

D.

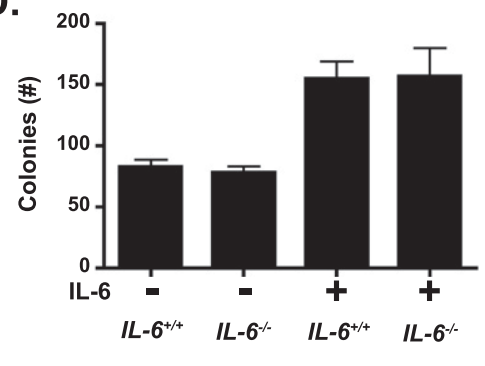

Figure 2. IL-6 promotes the differentiation of normal and neoplastic B cells. (A) A pie chart displaying the IgM status of $E \mu-m y c ; I L-6^{+/+}(n=32)$ and $E \mu-m y c ; I L-6^{-/-}$ $(n=36)$ B-cell lymphomas. The hatched area represents multiclonal tumors that were partially IgM-positive and -negative. (B) A graph showing the percentage of $\mathrm{CD}_{1} 9^{+} / \mathrm{IgM}^{+}$cells within the bone marrow of $I L-6^{+/+}(n=11)$ and $I L-6^{-/-}(n=39)$ mice. Each dot represents an individual mouse, with a line demarcating the mean for each cohort. $(C)$ A graph showing the fold change in the number of live pro/pre- or immature B cells after $72 \mathrm{~h}$ in culture in the presence or absence of $10 \mathrm{ng} / \mathrm{mL}$ recombinant IL- 6 . The data are represented as mean $\pm \mathrm{SD}(n \geq 6$ for two independent experiments). (D) A bar graph displaying the number of B-cell colonies in a methylcellulose colony formation assay for B-cell progenitor number. Bone marrow from $I L-6^{+/+}$and $I L-6^{-/-}$mice was treated with IL-7 and SCF in the presence or absence of IL- 6 for $7 \mathrm{~d}$, at which point colonies were counted. The data are shown as mean $\pm \operatorname{SEM}(n=6$ for two independent experiments). 
we observed changes associated with the presence of the $E \mu$-myc transgene, but no significant differences associated with IL-6 status (data not shown). Together, these results suggest that IL-6 deficiency results in a block early in the transition from pre- to immature B cells in wildtype and $E \mu$-myc mice.

Many paracrine survival signals such as IL-7, SCF, Notch, and TPO act at specific stages of hematopoietic development (Wang et al. 2006). To determine whether IL-6 directly promotes B-cell maturation, we isolated pro/ pre- and immature B cells from the bone marrow of wildtype mice. Pure populations of B cells were then plated in vitro in B-cell medium containing IL-7 and SCF with or without IL-6. Seventy-two hours later, we measured cell number and the percentage of pro/pre- and immature $B$ cells in all samples using flow cytometry. Here we observed that while IL-6 has no direct or indirect effect on pro/pre-B cells in vitro, it directly promotes the survival or proliferation of immature B cells (Fig. 2C; Supplemental Fig. S2C).

To address the possibility that the B-cell maturation defect we saw in $I L-6^{-/-}$mice results from a defect in the B-cell progenitor population, we performed a pre-B-cell methylcellulose colony formation assay. In this assay, cells from $I L-6^{-1-}$ or wild-type bone marrow were tested for their ability to form colonies of pre/pro-B cells in the presence or absence of recombinant IL- 6 . Here, we observed that bone marrow cells from $I L-6^{-/-}$and wild-type mice produced the same number of colonies, suggesting that there is no defect in B-cell progenitor cell number or function in $I L-6^{-/-}$mice (Fig. 2D). The addition of recombinant IL-6 to either $I L-6^{-/-}$or wild-type bone marrow resulted in a twofold increase in colony number, demonstrating that paracrine IL-6 can directly promote a minor survival benefit to B-cell progenitor cells in vitro. Although we observed an increase in colony number, we saw no significant differences in size, viability, or differentiation in the resulting B-cell colonies. Together, these data suggest that IL-6 promotes progenitor but not more mature B-cell differentiation and survival and that the accelerated tumorigenesis seen in $E \mu-m y c ; I L-\sigma^{-/-}$mice may occur due to impaired early B-cell development. These data are consistent with multiple reports showing that the predominant cell of origin in $E \mu$-myc mice is a committed B-cell progenitor (Strasser et al. 1990; Lindeman et al. 1994; Kelly et al. 2007b, 2011).

\section{IL-6 loss results in systemic changes to the bone marrow microenvironment that indirectly block B-cell development}

The minimal survival benefit conferred by IL- 6 on immature B cells in vitro suggested that perhaps other factors that promote B-cell development in the bone marrow microenvironment were altered in $I L-6^{-/-}$mice. To determine whether IL-6 deficiency could indirectly affect B-cell development, we measured the levels of 32 cytokines, chemokines, and growth factors within the bone marrow of wild-type and $I L-6^{-/-}$mice. Interestingly, $I L-6^{-/-}$mice showed significantly decreased levels of
IL-1 $\alpha$, IL-1 $\beta$, IL-10, IL-12, IL-13, IL-15, G-CSF, and GMCSF when compared with control mice, while the levels of the remaining 24 factors were unchanged (Fig. 3A; Supplemental Table S1). This suggests that IL-6 acts as a key upstream regulator of the bone marrow microenvironment and promotes expression of diverse molecules implicated in many biological processes, including monocyte development, T- and B-cell development or effector function, and the regulation of inflammation.

Since several of the eight factors depleted in the absence of IL-6 are reported to regulate B-cell biology, we next examined whether these factors affect B-cell development or survival in vitro. Whole bone marrow from wild-type mice was harvested and plated with IL-7 and SCF on a bone marrow stromal cell (BMSC) feeder population. Cells were then either left untreated or treated with recombinant IL-1 $\alpha$, IL-1 $\beta$, IL-10, IL-12, IL-13, IL-15, G-CSF, and GM-CSF as an eight-factor cocktail. Seventy-two hours later, we measured both pro/pre- and immature B-cell percentage within the culture as well as the total cell number to determine the absolute change in B-cell representation. Notably, the eight-factor cocktail robustly reduced the number of pro/pre-B cells while increasing the number of immature B cells (Supplemental Fig. S3A). Thus, IL- 6 deficiency results in profound changes in the bone marrow microenvironment that both directly and indirectly prevent B-cell maturation.

To determine whether B-cell maturation defects were due to a direct effect of these eight factors on B cells, we used flow cytometry to sort pure populations of pro/preor immature B cells from the bone marrow of wild-type mice and plated cells with IL-7 and SCF either with or without a BMSC layer. Cells were then either left untreated or treated with the eight factors in combination. Interestingly, in both assays, the eight-factor cocktail directly promoted both immature B-cell survival and an increased immature to pro/pre-B-cell ratio (Fig. 3B; Supplemental Fig. S3B). As this phenotype could result from either changes in B-cell survival or differentiation status, we examined B-cell maturation following the addition of the eight-factor cocktail to pro/pre-B cells in vitro. In this context, the eight-factor cocktail directly promoted pro/pre-B-cell maturation into immature B cells (Fig. 3C). Notably, we also observed that addition of the eightfactor cocktail directly promoted pro/pre-B-cell death while reducing basal immature B-cell death (Fig. 3D). Thus, the eight-factor cocktail promotes the survival of immature $\mathrm{B}$ cells while promoting cell death and differentiation of pro/pre-B cells.

To examine which of these eight factors was responsible for these B-cell phenotypes, we again sorted pro/preor immature B cells and plated the cells in the presence of recombinant IL-7 and SCF. Cells were then treated with each component from the eight-factor cocktail as individual recombinant proteins. Seventy-two hours later, we measured the effect of each protein on pro/pre- or immature B-cell growth and survival. Here we observed that IL$1 \alpha$, IL-1 $\beta$, and IL-10 decreased pre/pro-B-cell survival, but, interestingly, IL-10 alone was able to phenocopy the effects of the eight-factor cocktail on both pre/pre- and 
A.

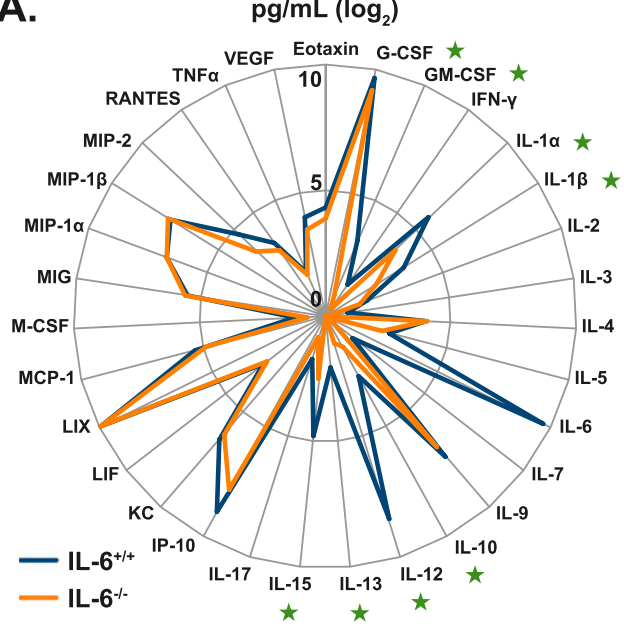

C.

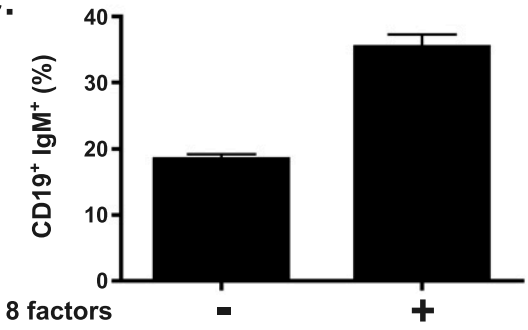

E.

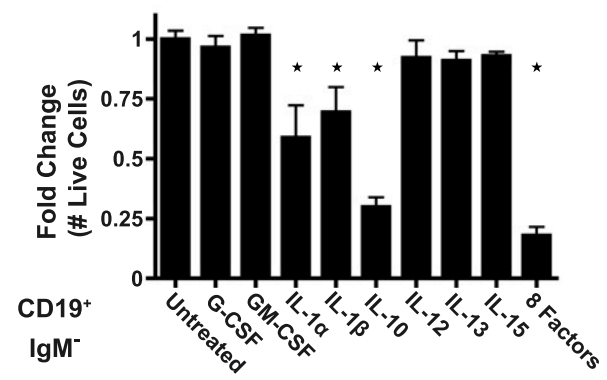

B.

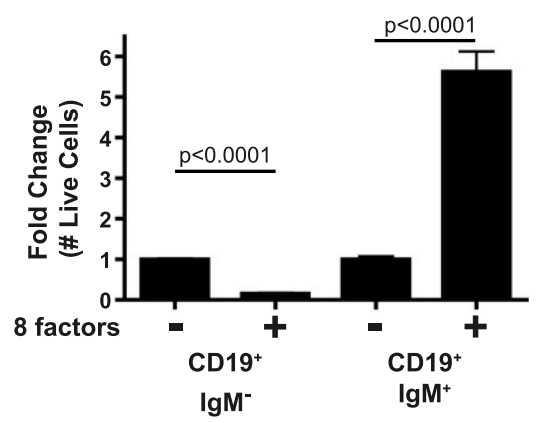

D.
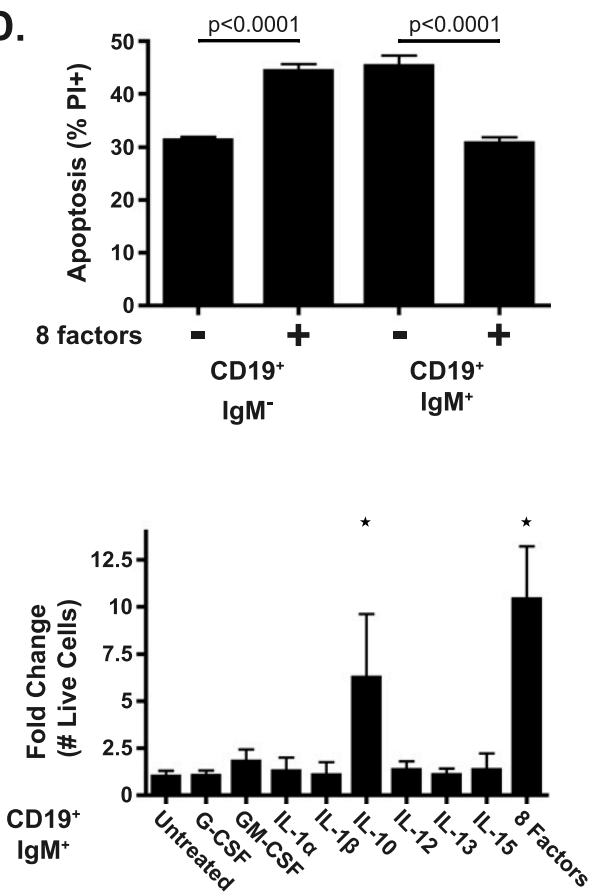

Figure 3. The absence of IL-6 alters the bone marrow microenvironment to indirectly reduce pre/pro-to-immature B-cell maturation. (A) A radar chart displaying the concentrations of 32 cytokines and chemokines in the bone marrow of $I L-6^{+/+}(n=16)$ and $I L-6^{-/-}(n=$ 18) mice. The concentrations are displayed as $\log _{2}$ transformed picograms per milliliter. Significant differences between $I L-6^{+/+}$and $I L-6^{-/-}$bone marrow concentrations are demarcated with stars $(P<0.01)$. (B) A bar graph showing the fold change in live $\mathrm{CD}^{-} 9^{+} / \mathrm{IgM}^{-}$ and $\mathrm{CD} 19^{+} / \mathrm{IgM}^{+} \mathrm{B}$ cells FACS-sorted and grown for $72 \mathrm{~h}$ with IL-7 and SCF in the presence or absence of the eight-factor cocktail. The data are represented as mean $\pm \mathrm{SD}\left(n=9\right.$ for three independent experiments). (C) A graph depicting the percentage of maturing CD19 ${ }^{+} /$ $\mathrm{IgM}^{+} \mathrm{B}$ cells in a FACS-sorted population of CD19+ $\mathrm{IgM}^{-} \mathrm{B}$ cells after $72 \mathrm{~h}$ in vitro with IL-7 and SCF with or without the eight-factor cocktail. The data are represented as mean \pm SEM $(n=3$ independent experiments). (D) A graph showing the percent of basal apoptosis in pure populations of $\mathrm{CD}_{1} 9^{+} / \mathrm{IgM}^{-}$and $\mathrm{CD} 19^{+} / \mathrm{IgM}^{+} \mathrm{B}$ cells FACS-sorted and grown for $72 \mathrm{~h}$ with IL-7 and SCF in the presence or absence of the eight-factor cocktail. The data are represented as mean \pm SEM ( $n=9$ for three independent experiments). (E) Two bar graphs showing the fold change in cell number for pure populations of $\mathrm{CD}_{1} 9^{+} / \operatorname{IgM}^{-}($left $)$and $\mathrm{CD} 19^{+} / \operatorname{IgM}^{+}$(right) B cells FACS-sorted and grown for $72 \mathrm{~h}$ with IL-7 and SCF with the indicated recombinant proteins. The data are represented as mean \pm SD $(n \geq 3$ for three independent experiments). ( $\star$ ) $P \leq 0.05$.

immature B cells (Fig. 3E). Thus, IL-10 exerts distinct effects on cells at different stages of B-cell development, promoting pro/pre-B-cell death and immature B-cell survival or growth. Furthermore, we observed that IL-6 and IL-10 promote immature B-cell survival or growth in an additive manner (Supplemental Fig. S3C). Neither IL-6 nor IL-10 affect pre/pro-B-cell survival in vitro in the absence of IL-7 and SCF, suggesting that these two proteins modulate survival and growth in a context-specific manner dependent on both developmental status and the 
presence of other developmental inputs (Supplemental Fig. S3D). To determine whether IL-6 and IL-10 promote the growth or survival of immature B cells, we sorted immature B cells and plated cells with or without both factors. Seventy-two hours later, we measured the cell cycle profile of these cells. In the presence of IL- 6 and IL10 , we observed a decrease in the sub- $G_{1}$ fraction but no change in the number of cells in $S$ phase, suggesting that these two cytokines promote immature B-cell survival but not growth (Supplemental Fig. S3E). Thus, IL-6 deficiency results in decreased levels of multiple factors, some of which promote B-cell maturation and survival at the pre/ pro-to-immature B-cell transition.

\section{Impaired B-cell development promotes the survival of premalignant $B$ cells}

Previous work in the E$\mu$-myc model has shown that precursor B cells show enhanced resistance to Myc-induced apoptosis and are the cells of origin for many $E \mu$-myc lymphomas (Strasser et al. 1990; Lindeman et al. 1994; Kelly et al. 2007b, 2011). In the $E \mu$-myc model, induction of myc transcription in pro/pre-B cells following rearrangement of the heavy chain locus results in a drastic increase in the number of pro/pre-B cells and a large decrease in the number of immature B cells due to apoptosis. Thus, we reasoned that if the combination of IL- $1 \alpha$, IL-1 $\beta$, IL-6, and IL-10 promotes pro/pre-B-cell differentiation into immature B cells, then $E \mu-m y c ; I L-6^{-/-}$mice should have fewer apoptotic B cells than $I L-6$-proficient $E \mu$-myc mice. To test this hypothesis, we examined basal cell death in the B-cell compartment of premalignant mice. Using flow cytometry, we observed that $E \mu$-myc; $I L-6^{-/-}$mice display, on average, twofold fewer apoptotic B cells than $I L$-6-proficient $E \mu$-myc mice, while there was no difference in the steady-state levels of B-cell death between wild-type and $I L-6^{-1-}$ mice (Fig. 4A). Here, this difference was due to a decrease in apoptosis in pro/pre-B cells and not immature B cells (Fig. 4B,C). Consistent with a survival/differentiation defect, rather than a growth effect, we observed no significant differences in the cell cycle profiles of B cells at the same differentiation states in $E \mu-m y c ; I L-\sigma^{+/+}$and $E \mu-m y c ; I L-6^{-/-}$mice (Supplemental Fig. S4). These data are consistent with a model by which impaired B-cell development-associated with the combined loss of IL- 6 and a decrease in IL- $1 \alpha$, IL-1 $\beta$, and IL-10 levels-leads to increased numbers and enhanced survival of early B cells and accelerated lymphomagenesis.

\section{IL-6 promotes HSC survival in vitro and in vivo}

Given a role for IL-6 in B-cell differentiation and tumor suppression, we next sought to investigate the mechanism underlying delayed tumor development following adoptive transfer of $E \mu-m y c$ stem cells into $I L-6^{-/-}$recipient mice. A major experimental difference between germline and adoptive transfer models is the requirement for HSCs to engraft and expand in the transplant model. Recent work has shown that paracrine factors such as $\mathrm{TNF} \alpha$ are important modulators of HSC reconstitution,
A.

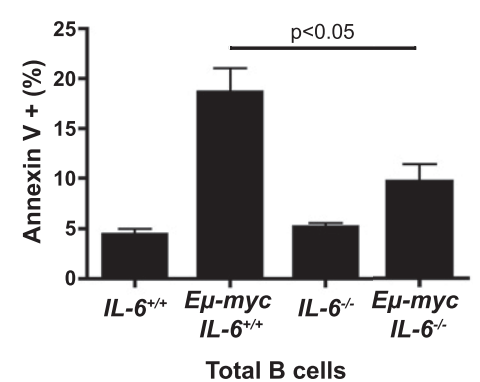

B.

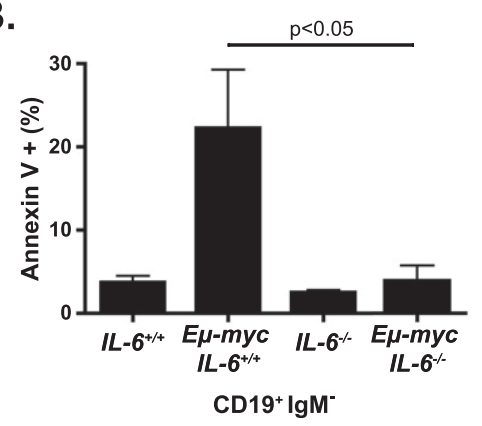

C.

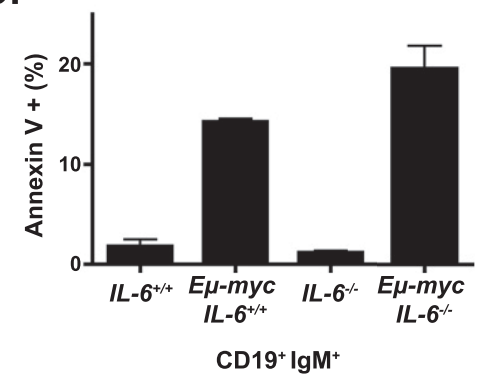

Figure 4. IL-6 induces B-cell apoptosis during $E \mu-M y c$ lymphomagenesis. (A) A graph depicting the percentage of Annexin $\mathrm{V}^{+}$ cells in vivo in the bone marrow of $I L-6^{+/+}(n=18), I L-6^{-/-}(n=$ 20), $E \mu-m y c ; I L-\sigma^{+/+}(n=14)$, and $E \mu-m y c ; I L-\sigma^{-/}(n=7)$ mice. The data are represented as mean \pm SEM. $(B)$ A graph depicting the percentage of Annexin $\mathrm{V}^{+} \mathrm{CD} 19^{+} \mathrm{IgM}^{-}$pro/pre-B cells in vivo in the bone marrow of $I L-6^{+/+}(n=12), I L-6^{-/-}(n=14)$, $E \mu-m y c ; I L-6^{+/+}(n=3)$, and $E \mu-m y c ; I L-6^{-/-}(n=4)$ mice. The data are represented as mean \pm SEM. (C) A graph depicting the percentage of Annexin $\mathrm{V}^{+} \mathrm{CD}^{+} 9^{+} \mathrm{IgM}^{+}$immature B cells in vivo in the bone marrow of $I L-6^{+/+}(n=12), I L-6^{-/-}(n=14)$, $E \mu-m y c ; I L-6^{+/+}(n=3)$, and $E \mu-m y c ; I L-6^{-/-}(n=4)$ mice. The data are represented as mean \pm SEM.

although they have no effect on steady-state HSCs (Pronk et al. 2011). Since IL-6 has been shown to promote cell survival in vivo in multiple experimental models, we asked whether IL-6 promotes HSC survival under stress in vitro (Kopf et al. 1994; Hilbert et al. 1995; Cressman et al. 1996; Sherr and DePinho 2000; Gilbert and Hemann 2010). Whole bone marrow from wild-type mice was plated in culture in the presence or absence of recombinant IL-6. Cells were then either left untreated or irradiated. Twenty-four hours following irradiation, all samples were analyzed by flow cytometry for hematopoietic stem and progenitor cell (HSPC) number (here defined as 
Lin $\left.^{-} \mathrm{Scal}^{+} \mathrm{c}-\mathrm{kit}^{+}\right)$. Here, IL-6 promoted the acute survival of HSPCs in response to both culture stress and DNA damage associated with irradiation (Fig. 5A,B). To test whether increased survival was due to the suppression of apoptosis or an alternate form of cell death, we sorted HSPCs from the bone marrow of mice and plated the cells in the presence or absence of IL-6. Here, IL-6 decreased the percentage of Annexin V-positive HSPCs both under normal culture stress and following irradiation (Fig. 5C). We also observed reduced induction of p21 and PUMA in irradiated HSPCs in the presence of IL-6 (Supplemental Fig. S5A,B). Together these data suggest that IL-6 acts directly on HSPCs to reduce p53-dependent apoptosis following irradiation.
To determine whether IL-6 similarly promotes HSC survival in vivo, we administered a sublethal dose of irradiation to wild-type and $I L-6^{-/-}$mice. Mice were then monitored for signs of bone marrow failure. While wildtype mice survived irradiation, $60 \%$ of $I L-6^{-/-}$mice developed terminal illness due to bone marrow failure (Fig. 5D). Thus, IL-6 promotes HSPC survival in vitro and in vivo. Indeed, IL-6 may more generally promote tissue homeostasis and repair following DNA damage, as we saw $I L-6^{-/-}$ mice lose significantly more weight following irradiation than wild-type mice (Supplemental Fig. S5C).

Notably, we also observed IL-6-dependent differences in basal HSPC homeostasis in vivo, as $I L-6^{-/-}$mice displayed an expanded HSPC pool relative to wild-type
A.

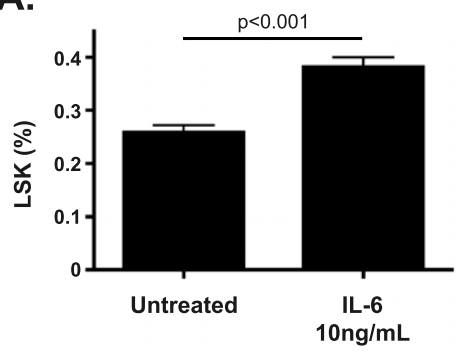

C.

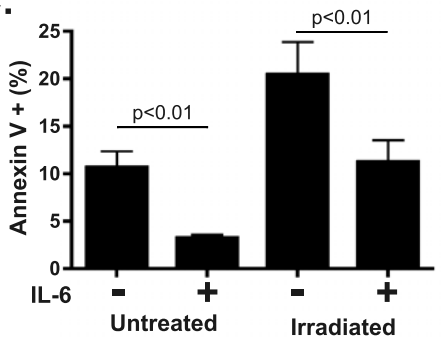

E.

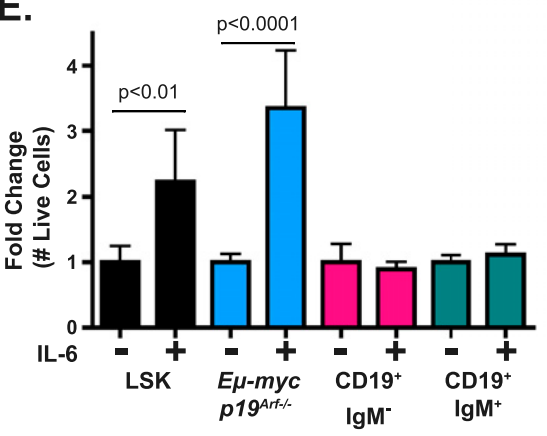

B.

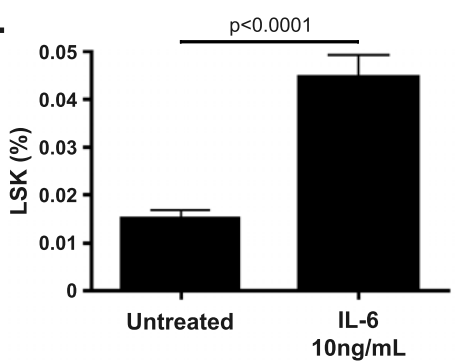

D.

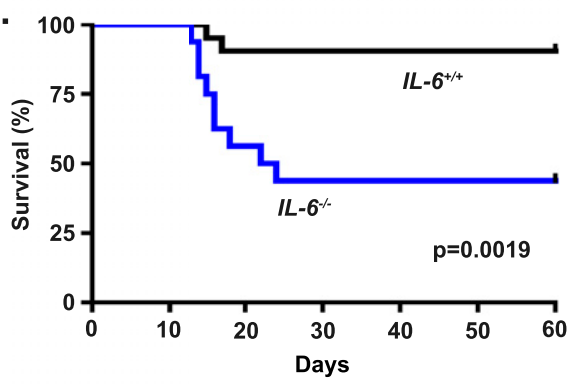

F.

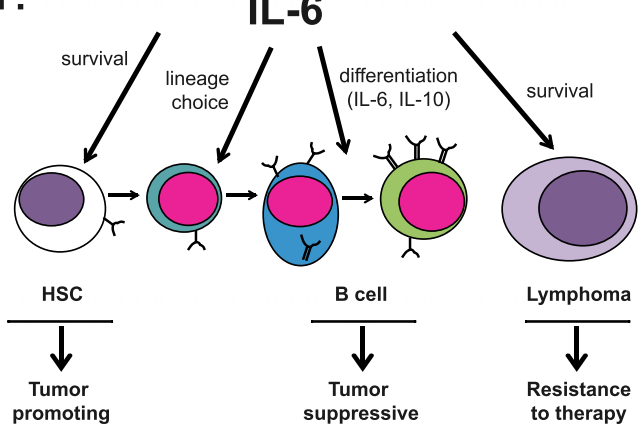

Figure 5. $I L-6$ status impacts HSC survival in vitro and in vivo. (A) A graph depicting the percent of $\mathrm{Lineage}^{-} \mathrm{Scal}^{+} \mathrm{Kit}^{+}(\mathrm{LSK}) \mathrm{cells}$ within a population of whole bone marrow cells treated with or without IL- 6 for $24 \mathrm{~h}$. The data are represented as mean \pm SEM $(n=6$ independent experiments). (B) A graph depicting the percent of LSK cells within a population of whole bone marrow cells irradiated with $4 \mathrm{~Gy}$ and treated with or without IL- 6 for $24 \mathrm{~h}$. The data are represented as mean \pm SEM ( $n=6$ independent experiments). (C) A graph depicting the percentage of Annexin $\mathrm{V}^{+}$cells in a pure population of LSK cells irradiated with 2 Gy and treated with or without IL-6 for $20 \mathrm{~h}$. The data are represented as mean $\pm \mathrm{SD}$ ( $n \geq 3$ for two independent experiments). (D) A Kaplan-Meier curve showing postirradiation survival of $I L-6^{+/+}(n=21)$ and $I L-6^{-/-}(n=16)$ mice. All mice were treated with 7.2 Gy of irradiation in a single dose. The $P$-value was calculated using a log-rank test. (E) A graph showing the fold change in live LSK, E $\mu-M y c p 19^{A r f-/-}, \mathrm{CD}^{-} 9^{+} / \mathrm{IgM}^{-}$, and CD19+ $\mathrm{IgM}^{+} \mathrm{B}$ cells at $48 \mathrm{~h}$ following irradiation with or without $10 \mathrm{ng} / \mathrm{mL} \mathrm{IL}-6$. The data are represented as mean \pm SEM (n $\geq 3$ for two independent experiments). (F) A model for the stage-specific effects of IL-6 during normal and neoplastic B-cell development. IL-6 promotes the survival of stem and tumor cells, the lineage commitment choice of bipotential committed progenitor cells (Reynaud et al. 2011), and the differentiation of pre/pro-B cells. 
mice. This expansion is characteristic of HSPC dysfunction and eventual exhaustion (Supplemental Fig. S5D). Interestingly, it has previously been reported that $I L-\sigma^{-/-}$ HSCs show impaired renewal capacity in serial competitive HSC reconstitution assays (Bernad et al. 1994). These data suggest that IL-6 deficiency results in impaired HSC expansion-a defect that may impair the outgrowth of tumor-promoting stem cells following adoptive transfer.

\section{Cancer cells co-opt stem cell survival signals}

Numerous studies have described similarities between adult stem cells and tumor-initiating cells. Factors such as Wnt, Hedgehog, and Notch promote self-renewal in adult stem cells within adult stem cell niches and in tumor-initiating cells within certain tumor microenvironments. It is less well understood whether most cancer cells co-opt survival factors important for stem cell survival and tissue regeneration following damage. To more carefully examine contexts in which IL-6 functions as a survival factor, we sorted HSPCs, pro/pre-B cells, immature B cells, and $E \mu-M y c$ lymphoma cells. Each cell type was plated in normal growth medium with or without IL- 6 and then left untreated or irradiated at a dose in which $95 \%$ of each cell type dies in the absence of IL-6. Notably, IL-6 promoted HSPC and lymphoma cell survival following irradiation, while normal B cells were equally sensitive to irradiation in the presence and absence of IL-6 (Fig. 5E). Thus, transformed cells can gain responsiveness to survival signals used by stem cells, while this protective buffer is lost during normal B-cell development. This suggests that a balance of tumor suppression and tissue regeneration occurs in which IL-6 promotes stem cell expansion, B-cell differentiation, and tumor cell survival.

\section{Discussion}

IL-6 is a proinflammatory cytokine critically required to orchestrate the immune response to viral and bacterial pathogens and for induction of the acute phase response (Heinrich et al. 1990; Harker et al. 2011; Kane et al. 2011; Teijaro et al. 2011). It is less well understood how IL-6 promotes normal tissue homeostasis and response to noninfectious tissue damage. IL-6 has been shown to promote T-cell survival both basally and in response to DNA damage (Kopf et al. 1994; Gilbert and Hemann 2010). IL-6 is also a critical survival factor during plasma cell maturation and for the pathogenesis of plasma cell tumors (Beagley et al. 1989; Hirano 1991; Hilbert et al. 1995; Hideshima et al. 2007; Rutsch et al. 2010). In nonhematopoietic tissues, IL-6 similarly promotes both cellular survival and tissue repair. For example, IL-6 plays a critical role in liver regeneration, fibrosis, and hepatocellular carcinoma tumorigenesis and has recently been implicated in resistance to therapy in both hepatocellular carcinoma and non-small-cell lung cancer (Cressman et al. 1996; Naugler et al. 2007; Hoshida et al. 2008; Krizhanovsky et al. 2008; Park et al. 2010; Yao et al. 2010).

Here, we uncovered a new role for IL-6 as a paracrine signal required for the survival and development of multiple hematopoietic cell types. IL-6-deficient mice are dramatically more sensitive to bone marrow failure following irradiation than their wild-type counterparts, and IL-6 acts to directly promote HSPC survival in vitro. IL-6 also promotes immature B-cell and B-cell progenitor cell survival, but not the survival of the intermediates between these two cell types. This suggests that cells within the same developmental lineage vary in their responsiveness to IL-6 as a prosurvival cue. Furthermore, in the bone marrow, IL-6-deficient mice show a dramatic decrease in key molecules that promote myeloid development, B-cell maturation, and inflammation. Our work and recent work from others suggest that normal and malignant development within the myeloid and lymphoid lineages is dynamically controlled by IL-6 in a stage- and oncogene-specific manner (Cheung and Van Ness 2002; Reynaud et al. 2011). Thus, IL-6 signaling is significantly more complex than anticipated, with context-specific information dictating how this pleiotropic cytokine affects the survival and maturation of hematopoietic cells.

Proper differentiation and survival of developing hematopoietic cells within the bone marrow microenvironment require the input of multiple paracrine signals. For example, during B-cell development, paracrine IL-7, SCF, and Flt-3 ligand are required for pro-B-cell differentiation (Nagasawa 2006). To ensure directional development, paracrine developmental factors often form positive feed-forward loops during differentiation. IL-7 induces the transcription of EBF1 and, indirectly, Pax5, and these transcription factors together induce and maintain their own expression and B-cell lineage commitment (Kikuchi et al. 2005, 2008). Here, we identify IL-10 as a key prodifferentiation factor critically important for the pro/ pre-to-immature B-cell transition and for survival of immature B cells in vitro. IL-6-deficient mice have a developmental block in the B-cell lineage, in part due to loss of IL-6, but also due to dramatically decreased IL-10 levels. Thus, the absence of a pleiotropic extracellular ligand such as IL-6 causes widespread changes in the bone marrow, resulting in multiple direct and indirect survival and differentiation defects.

In all stages of B-cell development, genetic alterations that inhibit developmental progression can promote tumorigenesis. Deregulation of genes encoding B-cell transcription factors such as Ikaros, Ebf1, Pax5, Bcl-6, and Blimp1 all inhibit B-cell development and promote leukemia or lymphoma development (Pasqualucci et al. 2001, 2006; Mullighan et al. 2009; Heltemes-Harris et al. 2011; O'Brien et al. 2011). Here, we show that cell-nonautonomous alterations to the tumor microenvironment that block B-cell maturation can also promote lymphoma development. Thus, normal B-cell development requires integration of multiple paracrine signals that promote feed-forward transcriptional commitment to the B-cell lineage, and alterations to this process accelerate tumor development (Bryder and Sigvardsson 2010). Notably, while IL-6 does not directly affect B-cell survival during the developmental stage associated with transformation in this model, we see that B lymphoma cells can evolve to co-opt tissuespecific stem cell survival factors. Specifically, following 
transformation, IL-6 signaling can promote survival in response to apoptotic stress. Thus, tumor cells can co-opt mechanisms of stem cell survival. This result is consistent with previous work showing that lymphomas readily adapt stem cell characteristics, including high engraftment rates in transplant experiments (Kelly et al. 2007a).

Mouse models of hematopoietic malignancy have provided deep insight into the biology of leukemias and lymphomas (Hemann 2012). These models are experimentally tractable, as stem cells and tumors can be transplanted into large cohorts of syngeneic recipient mice to study both tumor development and response to therapy. However, our data suggest that transplant-based approaches may also yield confounding results in select situations. In this study, autochthonous and transplant approaches produced apparently conflicting outcomes, providing a unique example of a cytokine that can either promote or delay tumor onset, depending on the construction of the mouse model. While the transplant setting highlighted a critical role for IL- 6 following adoptive transfer, it obscured the protumorigenic effects of IL- 6 deficiency. Thus, transplant-based mouse models need to be viewed with particular caution in dissecting the role of paracrine factors during oncogenic transformation.

\section{Materials and methods}

Mice

C57BL/6 E $\mu-M y c$ and C57BL/6 IL- $6^{-1-}$ mice were purchased from Jackson Laboratories. $E \mu-M y c$ and $I L-\sigma^{-/-}$mice were crossed to generate $E \mu-M y c ; I L-6^{-1-}$ mice. For the $E \mu-M y c$ fetal HSC transplant model, C57BL/6 female mice were mated to C57BL/6 E $\mu$-Myc males. At embryonic day 13.5 (E13.5), pregnant female mice were sacrificed, and individual fetal livers were manually dissociated and frozen. Five hours prior to transplantation, C57BL/6 IL- $6^{+/+}$and C57BL/6 IL- $6^{-/-}$recipient mice were irradiated with $8.5 \mathrm{~Gy}$. All mice were then tail vein-injected with 2 million freshly thawed $E \mu-M y c$ fetal liver cells. All mice were monitored for tumor onset by palpation. The short-term fetal liver HSC engraftment assay was performed as described above. Twenty-four hours following injection, mice were sacrificed, and the percentage of $\mathrm{GFP}^{+}$fetal liver cells present in the bone marrow was measured by flow cytometry. For the bone marrow failure and weight loss assay, 6- to 8-wk-old C57BL/6 IL- $6^{+/+}$and C57BL/6 IL- $6^{-1-}$ mice were irradiated with 7.2 or 8.5 Gy using a $137^{\mathrm{Cs}}$ irradiator $(\gamma$ cell 40 ) at a dose rate of $\sim 70 \mathrm{cGy} / \mathrm{min}$. Mice irradiated with 8.5 Gy were reconstituted as described above. All mice were closely monitored for signs of bone marrow failure or excessive weight loss. The Massachusetts Institute of Technology Department of Comparative Medicine approved all procedures described in this work.

\section{Cell culture and chemicals}

B cells and $E \mu-M y c$ and $E \mu-M y c ; p 19^{A r f-/-}$ mouse B-cell lymphomas were cultured in B-cell medium (45\% DMEM/45\% IMDM $/ 10 \%$ FBS, supplemented with $2 \mathrm{mM} \mathrm{L-glutamine,} 50 \mu \mathrm{M}$ $\beta$-mercaptoethanol). B-cell cultures also contained $10 \mathrm{ng} / \mathrm{mL}$ IL-7 and SCF (Peprotech). Bone marrow-derived stromal cells were used as feeder cells for the B cells. HSPCs were cultured in X-VIVO 10/10\% FBS (Lonza). Fetal liver HSCs for the engraftment assay were cultured for $6 \mathrm{~d}$ in IL-3, IL-6, and SCF supplemented with WEHI-conditioned medium as described previously (Hemann et al. 2005). Retroviral-mediated gene transfer to label fetal liver HSCs with GFP was performed using Phoenix packaging cells as previously described (Hemann et al. 2005). IL-6 and all other recombinant proteins were used at $10 \mathrm{ng} / \mathrm{mL}$ (Peprotech).

\section{Hematopoietic cell sorting and analysis by flow cytometry}

Whole bone marrow from the tibia and femur of 6- to 8-wk-old C57BL $/ 6$ IL- $6^{+/+}$or C57BL/6 IL-6 ${ }^{-/-}$mice was flushed into B-cell medium or X-VIVO 10 medium and manually dissociated. The bone marrow was filtered through a $35-\mu \mathrm{m}$ cell strainer and washed once in PBS $/ 10 \%$ FBS. The bone marrow was then stained in PBS/10\% FBS for $1 \mathrm{~h}$ at room temperature. HSPCs were analyzed and sorted as the $\mathrm{Scal}^{+} / \mathrm{c}-\mathrm{Kit}^{+} /$Lineage $^{-}$fraction of bone marrow. The lineage cocktail of antibodies included $\alpha$-B220, $\alpha$-CD3, $\alpha$-CD4, $\alpha$-CD8, $\alpha$-CD11b, $\alpha$-CD11c, $\alpha$-CD19, $\alpha$-GR-1, and $\alpha$-Ter119. To sort and analyze B cells, whole bone marrow was incubated with $\alpha$-CD19 and $\alpha$-IgM antibodies. The $\mathrm{CD} 19^{+}$fraction was used to define all B cells and then gated as

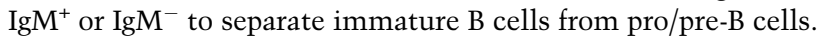
This same designation was used to define B-cell lymphoma developmental status. All antibodies for flow cytometry were purchased from BD Bioscience or eBioscience and used at 0.05 $\mathrm{mg} / \mathrm{mL}$. To analyze apoptosis rates in vivo, Annexin V staining (eBioscience) was performed on whole bone marrow from individual mice according to the manufacturer's protocol. All flow cytometry cell sorting was performed using either a FACS Aria II or MoFlo II (BD Biosciences and Beckman Coulter). All flow cytometry analysis was performed using a FACS Scan or LSR II (BD Biosciences).

\section{In vitro viability and cell growth assays}

For the pre-B-cell methylcellulose colony formation assay, bone marrow from 6- to 8-wk-old female C57BL/6 IL-6 $6^{+/+}$or C57BL/6 $I L-6^{-1-}$ mice was isolated, and the colony formation assay was performed as described by the manufacturer (Stem Cell Technologies). For all in vitro cell growth and survival assays, bone marrow from 6- to 8-wk-old female C57BL/6 IL- $6^{+/+}$or C57BL/6 $I L-6^{-1-}$ mice was isolated and FACS-sorted as described above. For all B-cell assays, 250,000 FACS-sorted CD19 ${ }^{+} / \mathrm{IgM}^{-}$or CD19 ${ }^{+} /$ $\mathrm{IgM}^{-}$cells were plated, treated in vitro as described, and analyzed $72 \mathrm{~h}$ later for cell number and developmental status. For the comparative irradiation experiment, HSPCs, pro/pre-B cells, and immature B cells were sorted from the bone marrow of wild-type mice as described above. Ten-thousand of each of the four cell types were plated in a 96-well plate and irradiated with 2-2.5 Gy (HSPCs and B cells) or 3.5 Gy (E $\left.\mu-M y c ; p 19^{\text {Arf-/- }}\right)$. Live-cell number or Annexin V status was measured by FACS analysis $48 \mathrm{~h}$ following irradiation as described above.

\section{Luminex cytokine measurements}

Bone marrow from individual mice was flushed from a single femur and tibia into B-cell medium. Bone marrow was manually dissociated and allowed to condition medium for $3 \mathrm{~h}$ at $37^{\circ} \mathrm{C}$. Samples were concentrated using Amicon Ultracel 3k centrifugal filters. All sample values were normalized by weight and concentration factor. Multiplexed luminex assays for chemokine and cytokine levels were preformed as described by the manufacturer by Eve Technologies.

\section{Histological analysis}

Formalin fixed, paraffin-embedded tissue sections were stained with hematoxylin and eosin for routine examination. 


\section{Quantitative RT-PCR}

Cells were harvested using trypsin (Invitrogen), and total RNA was isolated using the RNeasy microkit (Qiagen) according to manufacturer's instructions. RNA was converted to cDNA using M-MLV reverse transcriptase under standard conditions with random hexamer primers and RNaseOUT (Invitrogen). Quantitative PCR reactions were set up using the iQ SYBR Green Supermix (Bio-Rad) according to the manufacturer's instructions. Reactions were run on a Bio-Rad iCycler thermal cycler. Primer sequences for PUMA, p21, and GAPDH were as follows: PUMA, 5'-TGTCGATGCTGCTCTTCTTG-3' and 3'-GTGTG GAGGAGGAGGAGTGG-5'; p21，5'-CCAGGCCAAGATGGT GTCTT-3' and 3'-TGAGAAAGGATCAGCCATTGC-5'; and GA PDH, 5' -AGAACATCATCCCTGCATCC-3' and 3'-CACATTG GGGGTAGGAACAC-5'.

\section{Cell cycle analysis}

Cells were resuspended in $2 \%$ FBS/PBS and fixed in ice-cold ethanol at a final concentration of $75 \%$ ethanol while vortexing. Cells were fixed for $1 \mathrm{~h}$ at $4^{\circ} \mathrm{C}$. Cells were rehydrated and washed once in PBS. Cells were then stained in $3.8 \mathrm{mM}$ sodium citrate, $50 \mu \mathrm{g} / \mathrm{mL}$ propidium iodide, and $0.2 \mathrm{mg} / \mathrm{mL}$ RNase in PBS for $3 \mathrm{~h}$ at room temperature.

\section{Statistical analysis}

Statistical analysis was performed using GraphPad Prism4 software. Two-tailed Student's $t$-tests were used, as indicated. Error bars represent mean \pm SEM or SD as noted. For comparison of Kaplan-Meier survival curves, a log-rank test was used. A $\chi^{2}$ test was used to evaluate $E \mu-M y c$ and $E \mu$ - $m y c ; I L-\sigma^{-/}$differentiation status.

\section{Acknowledgments}

We acknowledge Glen Paradis and the Koch Institute Flow Cytometry Core Facility for advice and services. We are grateful to Corbin Meacham and Justin Pritchard for critical reading of the manuscript, and the entire Hemann laboratory for helpful discussions. M.T.H. is the Eisen and Chang Career Development Associate Professor of Biology and is supported by NIH RO1 CA128803 and the Ludwig Center for Molecular Oncology at MIT. L.A.G. is supported by a Virginia and DK Ludwig Graduate Fellowship.

\section{References}

Ashton GH, Morton JP, Myant K, Phesse TJ, Ridgway RA, Marsh V, Wilkins JA, Athineos D, Muncan V, Kemp R, et al. 2010. Focal adhesion kinase is required for intestinal regeneration and tumorigenesis downstream of Wnt/c-Myc signaling. Dev Cell 19: 259-269.

Beagley KW, Eldridge JH, Lee F, Kiyono H, Everson MP, Koopman WJ, Hirano T, Kishimoto T, McGhee JR. 1989. Interleukins and IgA synthesis. Human and murine interleukin 6 induce high rate IgA secretion in IgA-committed B cells. J Exp Med 169: 2133-2148.

Beltrami AP, Barlucchi L, Torella D, Baker M, Limana F, Chimenti S, Kasahara H, Rota M, Musso E, Urbanek K, et al. 2003. Adult cardiac stem cells are multipotent and support myocardial regeneration. Cell 114: 763-776.

Bernad A, Kopf M, Kulbacki R, Weich N, Koehler G, GutierrezRamos JC. 1994. Interleukin-6 is required in vivo for the regulation of stem cells and committed progenitors of the hematopoietic system. Immunity 1: 725-731.
Blanpain C, Mohrin M, Sotiropoulou PA, Passegue E. 2011. DNA-damage response in tissue-specific and cancer stem cells. Cell Stem Cell 8: 16-29.

Bryder D, Sigvardsson M. 2010. Shaping up a lineage-lessons from B lymphopoesis. Curr Opin Immunol 22: 148-153.

Burchill MA, Goetz CA, Prlic M, O'Neil JJ, Harmon IR, Bensinger SJ, Turka LA, Brennan P, Jameson SC, Farrar MA. 2003. Distinct effects of STAT5 activation on $\mathrm{CD}^{+}$and $\mathrm{CD}^{+} \mathrm{T}$ cell homeostasis: Development of $\mathrm{CD} 4^{+} \mathrm{CD} 25^{+}$regulatory $\mathrm{T}$ cells versus $\mathrm{CD}^{+}$memory T cells. J Immunol 171: 5853-5864.

Butler JM, Nolan DJ, Vertes EL, Varnum-Finney B, Kobayashi H, Hooper AT, Seandel M, Shido K, White IA, Kobayashi M, et al. 2010. Endothelial cells are essential for the self-renewal and repopulation of Notch-dependent hematopoietic stem cells. Cell Stem Cell 6: 251-264.

Cheung WC, Van Ness B. 2002. Distinct IL-6 signal transduction leads to growth arrest and death in B cells or growth promotion and cell survival in myeloma cells. Leukemia 16: 1182-1188.

Cressman DE, Greenbaum LE, DeAngelis RA, Ciliberto G, Furth EE, Poli V, Taub R. 1996. Liver failure and defective hepatocyte regeneration in interleukin-6-deficient mice. Science 274: 1379-1383.

Ettinger R, Sims GP, Fairhurst AM, Robbins R, da Silva YS, Spolski R, Leonard WJ, Lipsky PE. 2005. IL-21 induces differentiation of human naive and memory B cells into antibody-secreting plasma cells. J Immunol 175: 7867-7879.

Ettinger R, Sims GP, Robbins R, Withers D, Fischer RT, Grammer AC, Kuchen S, Lipsky PE. 2007. IL-21 and BAFF/ BLyS synergize in stimulating plasma cell differentiation from a unique population of human splenic memory B cells. J Immunol 178: 2872-2882.

Gilbert LA, Hemann MT. 2010. DNA damage-mediated induction of a chemoresistant niche. Cell 143: 355-366.

Haluska FG, Finver S, Tsujimoto Y, Croce CM. 1986. The t $(8 ; 14)$ chromosomal translocation occurring in B-cell malignancies results from mistakes in V-D-J joining. Nature 324: 158-161.

Hanahan D, Weinberg RA. 2000. The hallmarks of cancer. Cell 100: $57-70$.

Hanahan D, Weinberg RA. 2011. Hallmarks of cancer: The next generation. Cell 144: 646-674.

Hardy RR, Li YS, Allman D, Asano M, Gui M, Hayakawa K. 2000. B-cell commitment, development and selection. Immunol Rev 175: 23-32.

Harker JA, Lewis GM, Mack L, Zuniga EI. 2011. Late interleukin-6 escalates $T$ follicular helper cell responses and controls a chronic viral infection. Science 334: 825-829.

Harris AW, Pinkert CA, Crawford M, Langdon WY, Brinster RL, Adams JM. 1988. The E $\mu$-myc transgenic mouse. A model for high-incidence spontaneous lymphoma and leukemia of early B cells. I Exp Med 167: 353-371.

Heinrich PC, Castell JV, Andus T. 1990. Interleukin-6 and the acute phase response. Biochem I 265: 621-636.

Heltemes-Harris LM, Willette MJ, Ramsey LB, Qiu YH, Neeley ES, Zhang N, Thomas DA, Koeuth T, Baechler EC, Kornblau SM, et al. 2011. Ebf1 or Pax5 haploinsufficiency synergizes with STAT5 activation to initiate acute lymphoblastic leukemia. J Exp Med 208: 1135-1149.

Hemann MT. 2012. The development and use of genetically tractable preclinical mouse models. In Genetically engineered mice for cancer research (ed. JE Green, T Ried), pp. 477-495. Springer, New York.

Hemann MT, Bric A, Teruya-Feldstein J, Herbst A, Nilsson JA, Cordon-Cardo C, Cleveland JL, Tansey WP, Lowe SW. 2005. Evasion of the p53 tumour surveillance network by tumourderived MYC mutants. Nature 436: 807-811. 
Hideshima T, Mitsiades C, Tonon G, Richardson PG, Anderson KC. 2007. Understanding multiple myeloma pathogenesis in the bone marrow to identify new therapeutic targets. Nat Rev Cancer 7: 585-598.

Hilbert DM, Kopf M, Mock BA, Kohler G, Rudikoff S. 1995. Interleukin 6 is essential for in vivo development of $\mathrm{B}$ lineage neoplasms. J Exp Med 182: 243-248.

Hirano T. 1991. Interleukin 6 (IL-6) and its receptor: Their role in plasma cell neoplasias. Int J Cell Cloning 9: 166-184.

Hoshida Y, Villanueva A, Kobayashi M, Peix J, Chiang DY, Camargo A, Gupta S, Moore J, Wrobel MJ, Lerner J, et al. 2008. Gene expression in fixed tissues and outcome in hepatocellular carcinoma. N Engl J Med 359: 1995-2004.

Kane M, Case LK, Kopaskie K, Kozlova A, MacDearmid C, Chervonsky AV, Golovkina TV. 2011. Successful transmission of a retrovirus depends on the commensal microbiota. Science 334: 245-249.

Kelly PN, Dakic A, Adams JM, Nutt SL, Strasser A. 2007a. Tumor growth need not be driven by rare cancer stem cells. Science 317: 337.

Kelly PN, Puthalakath H, Adams JM, Strasser A. 2007b. Endogenous bcl-2 is not required for the development of E $\mu$-mycinduced B-cell lymphoma. Blood 109: 4907-4913.

Kelly PN, Grabow S, Delbridge AR, Strasser A, Adams JM. 2011. Endogenous Bcl-xL is essential for Myc-driven lymphomagenesis in mice. Blood 118: 6380-6386.

Kikuchi K, Lai AY, Hsu CL, Kondo M. 2005. IL-7 receptor signaling is necessary for stage transition in adult $\mathrm{B}$ cell development through up-regulation of EBF. J Exp Med 201: 1197-1203.

Kikuchi K, Kasai H, Watanabe A, Lai AY, Kondo M. 2008. IL-7 specifies B cell fate at the common lymphoid progenitor to pre-proB transition stage by maintaining early B cell factor expression. I Immunol 181: 383-392.

Kopf $M$, Baumann H, Freer G, Freudenberg M, Lamers $M$, Kishimoto T, Zinkernagel R, Bluethmann H, Kohler G. 1994. Impaired immune and acute-phase responses in in terleukin-6-deficient mice. Nature 368: 339-342.

Krizhanovsky V, Yon M, Dickins RA, Hearn S, Simon J, Miething C, Yee H, Zender L, Lowe SW. 2008. Senescence of activated stellate cells limits liver fibrosis. Cell 134: 657-667.

Kuchen S, Robbins R, Sims GP, Sheng C, Phillips TM, Lipsky PE, Ettinger R. 2007. Essential role of IL-21 in B cell activation, expansion, and plasma cell generation during $\mathrm{CD}^{+} \mathrm{T}$ cell-B cell collaboration. J Immunol 179: 5886-5896.

Lindeman GJ, Adams JM, Cory S, Harris AW. 1994. B-lymphoid to granulocytic switch during hematopoiesis in a transgenic mouse strain. Immunity 1: 517-527.

Mandal PK, Blanpain C, Rossi DJ. 2011. DNA damage response in adult stem cells: Pathways and consequences. Nat Rev Mol Cell Biol 12: 198-202.

Michaloglou C, Vredeveld LC, Soengas MS, Denoyelle C, Kuilman T, van der Horst CM, Majoor DM, Shay JW, Mooi WJ, Peeper DS. 2005. BRAFE600-associated senescence-like cell cycle arrest of human naevi. Nature 436: 720-724.

Mohrin M, Bourke E, Alexander D, Warr MR, Barry-Holson K, Le Beau MM, Morrison CG, Passegue E. 2010. Hematopoietic stem cell quiescence promotes error-prone DNA repair and mutagenesis. Cell Stem Cell 7: 174-185.

Mullighan CG, Su X, Zhang J, Radtke I, Phillips LA, Miller CB, Ma J, Liu W, Cheng C, Schulman BA, et al. 2009. Deletion of IKZF1 and prognosis in acute lymphoblastic leukemia. $N$ Engl J Med 360: 470-480.

Nagasawa T. 2006. Microenvironmental niches in the bone marrow required for B-cell development. Nat Rev Immunol 6: $107-116$.
Naugler WE, Sakurai T, Kim S, Maeda S, Kim K, Elsharkawy AM, Karin M. 2007. Gender disparity in liver cancer due to sex differences in MyD88-dependent IL-6 production. Science 317: 121-124.

O'Brien P, Morin P Jr, Ouellette RJ, Robichaud GA. 2011. The Pax-5 gene: A pluripotent regulator of B-cell differentiation and cancer disease. Cancer Res 71: 7345-7350.

Park EJ, Lee JH, Yu GY, He G, Ali SR, Holzer RG, Osterreicher $\mathrm{CH}$, Takahashi H, Karin M. 2010. Dietary and genetic obesity promote liver inflammation and tumorigenesis by enhancing IL-6 and TNF expression. Cell 140: 197-208.

Pasqualucci L, Neumeister P, Goossens T, Nanjangud G, Chaganti RS, Kuppers R, Dalla-Favera R. 2001. Hypermutation of multiple proto-oncogenes in B-cell diffuse largecell lymphomas. Nature 412: 341-346.

Pasqualucci L, Compagno M, Houldsworth J, Monti S, Grunn A, Nandula SV, Aster JC, Murty VV, Shipp MA, Dalla-Favera R. 2006. Inactivation of the PRDM1/BLIMP1 gene in diffuse large B cell lymphoma. J Exp Med 203: 311-317.

Pronk CJ, Veiby OP, Bryder D, Jacobsen SE. 2011. Tumor necrosis factor restricts hematopoietic stem cell activity in mice: Involvement of two distinct receptors. J Exp Med 208: 1563-1570.

Rempel RE, Mori S, Gasparetto M, Glozak MA, Andrechek ER, Adler SB, Laakso NM, Lagoo AS, Storms R, Smith C, et al. 2009. A role for E2F activities in determining the fate of Myc-induced lymphomagenesis. PLoS Genet 5: e1000640. doi: 10.1371/journal.pgen.1000640.

Reynaud D, Pietras E, Barry-Holson K, Mir A, Binnewies M, Jeanne M, Sala-Torra O, Radich JP, Passegue E. 2011. IL-6 controls leukemic multipotent progenitor cell fate and contributes to chronic myelogenous leukemia development. Cancer Cell 20: 661-673.

Rothenberg EV, Moore JE, Yui MA. 2008. Launching the T-celllineage developmental programme. Nat Rev Immunol 8: 9-21.

Rutsch S, Neppalli VT, Shin DM, DuBois W, Morse HC III, Goldschmidt H, Janz S. 2010. IL-6 and MYC collaborate in plasma cell tumor formation in mice. Blood 115: 17461754.

Serrano M, Lin AW, McCurrach ME, Beach D, Lowe SW. 1997. Oncogenic ras provokes premature cell senescence associated with accumulation of p53 and p16INK4a. Cell 88: 593602.

Sherr CJ, DePinho RA. 2000. Cellular senescence: Mitotic clock or culture shock? Cell 102: 407-410.

Strasser A, Harris AW, Bath ML, Cory S. 1990. Novel primitive lymphoid tumours induced in transgenic mice by cooperation between myc and bcl-2. Nature 348: 331-333.

Teijaro JR, Walsh KB, Cahalan S, Fremgen DM, Roberts E, Scott F, Martinborough E, Peach R, Oldstone MB, Rosen H. 2011. Endothelial cells are central orchestrators of cytokine amplification during influenza virus infection. Cell 146: 980-991.

Wang H, Pierce LJ, Spangrude GJ. 2006. Distinct roles of IL-7 and stem cell factor in the OP9-DL1 T-cell differentiation culture system. Exp Hematol 34: 1730-1740.

Yao Z, Fenoglio S, Gao DC, Camiolo M, Stiles B, Lindsted T, Schlederer M, Johns C, Altorki N, Mittal V, et al. 2010. TGF- $\beta$ IL-6 axis mediates selective and adaptive mechanisms of resistance to molecular targeted therapy in lung cancer. Proc Natl Acad Sci 107: 15535-15540.

Zindy F, Eischen CM, Randle DH, Kamijo T, Cleveland JL, Sherr CJ, Roussel MF. 1998. Myc signaling via the ARF tumor suppressor regulates p53-dependent apoptosis and immortalization. Genes \& Dev 12: 2424-2433. 


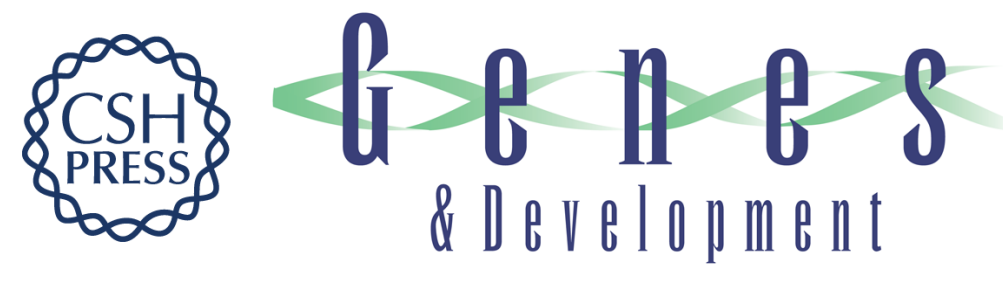

\section{Context-specific roles for paracrine IL-6 in lymphomagenesis}

Luke A. Gilbert and Michael T. Hemann

Genes Dev. 2012, 26:

Access the most recent version at doi:10.1101/gad.197590.112

Supplemental

Material

References

License

Email Alerting Service
http://genesdev.cshlp.org/content/suppl/2012/08/01/26.15.1758.DC1

This article cites 58 articles, 24 of which can be accessed free at: http://genesdev.cshlp.org/content/26/15/1758.full.html\#ref-list-1

Receive free email alerts when new articles cite this article - sign up in the box at the top right corner of the article or click here.

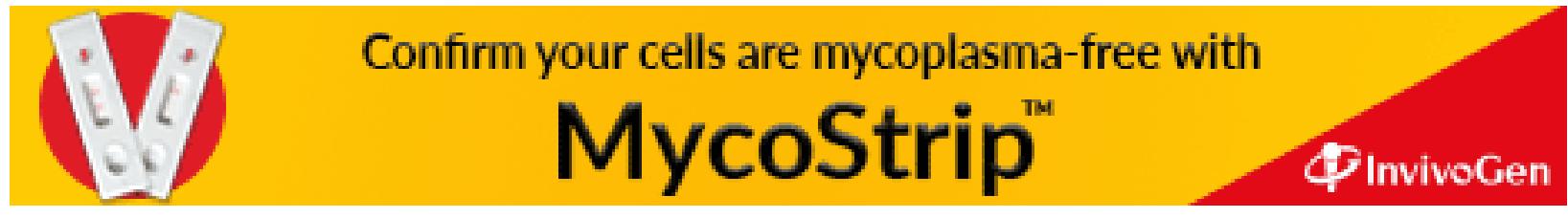

